\title{
Nickname as a Means of Linguistic Self-Presentation in the Internet of People with Eating Disorders
}

\section{Нікнейм як засіб мовної самопрезентації в Інтернеті осі6 з порушеннями харчової поведінки}

Vitaliia Shebanova ${ }^{1}$

Dr. in Psychology, Associate Professor, Professor of the Department of Practical Psychology
Віталія Шебанова ${ }^{1}$ доктор психологічних наук, доцент, професор кафедри практичної психології

\section{E-mail: vitaliashebanova@gmail.com orcid.org/0000-0002-1658-4691}

Yablonska Tetiana ${ }^{2}$

Doctor in Psychology, Senior Research Fellow, Assistant of Developmental

Psychology Department
Тетяна Яблонська ${ }^{2}$ доктор психологічних наук, старший науковий співробітник, асистент кафедри психології розвитку

E-mail: tyablonska@ukr.net orcid.org/0000-0001-7272-9691

Researcher ID: T-8367-2017

${ }^{1}$ Kherson State University

$\bowtie 27$, University Str., Kherson, Ukraine, 73000

2 Taras Shevchenko National University of Kyiv

60, Volodymyrska Str., Kyiv, Ukraine, 01033
${ }^{1}$ Херсонський державний університет вул. Університетська, 27, м. Херсон, Україна, 73000

${ }^{2}$ Київський національний університет імені Тараса Шевченка $\checkmark$ вул. Володимирська, 60 , м. Київ, Україна, 01033 
Original manuscript received September 23, 2018

Revised manuscript accepted March 01, 2019

\section{ABSTRACT}

The article analyzes the peculiarities of language self-presentation of Internet users. The results of the study of nicknames as means of linguistic self-presentation of persons with eating disorders in the specialized Internet forums are presented.

The psychological analysis of users' nicknames of sites of anorexic and overweight individuals is presented which gives an opportunity to assert that nicknames reflect the specific nutritional problem and self-administration of a person in connection with it. The predominance of the female audience of such sites is revealed and hence the greater urgency of the problem of standards of the body for women. In the process of analysis, on the basis of psycholinguistic and projective approaches, the main categories of nicknames are singled out: exo-decorative names; metaphorical, decorative and mysterious nicknames; mythical and fantasy characters; destructive, problem image; names that reflect the physical status, etc.

It has been established that nicknames as attributes of linguistic selfpresentation of users of specialized forums, is a symbolic projection of the discourse of their existence and reveals the features of real or desired body parameters; dissatisfaction with weight, with your body, yourself and life in general; fixation on the issue of nutrition and weight reduction; the desire to be fenced off from reality. Differences in the linguistic self-presentation of anorexics and overweight individuals are revealed, in particular, a more positive modality of self-presentation of overweight individuals; the representation of various categories of linguistic self-presentation in these groups which allows to assert the difference in the mechanisms of psychological protection in these groups of users. The analysis of the features of nicknames as a means of linguistic self-presentation is useful both for the purpose of psychodiagnostics of people with eating disorders, as well as in the process of developing and providing them with psychological assistance.

Key words: Internet communication, linguistic self-presentation of personality, discourse analysis, nickname, eating disorders.

\section{Вступ}

Інтернет-середовище як особливий вид інформаційного середовища є достатньо новим об'єктом психолінгвістичних досліджень. Водночас сучасні дослідники все частіше звертаються до проведення досліджень в Інтернет-мережі, зокрема до вивчення онлайн-комунікації. Враховуючи, що комунікація як обмін 
інформацією є складною інформаційно-знаковою системою, в якій задіяні різні мовні та позамовні символи/коди, зрозуміло, що під час комунікативного процесу суб'єкти керуються індивідуальними дискурсами згідно з комунікативними інтенціями та з урахуванням контексту ситуації.

Аналіз останніх досліджень. Сучасні дослідники (Войскунский, 2001; Горошко, 2008; Жичкина, 2004; Teufel, Hofer, Junne, Sauer, Zipfel \& Giel, 2013 та ін.) розглядають Інтернетмережу з психологічної точки зору як віртуальний простір, що широко використовується для спілкування, як засіб масової інформації та комунікації, що дозволяє людині розширити коло знайомств i встановити нові контакти. При цьому онлайнспілкування та пов'язані з ним феномени мовної самопрезентації особи, створення віртуального Я-образу виступають новою, актуальною та недостатньо дослідженою проблемою психології та психолінгвістики.

В Інтернеті активно взаємодіють різні користувачі та групи, зокрема, такі, що об'єднуються за спільними інтересами або проблемами. Однією $з$ проблем, що набуває все більшого масштабу, є проблема харчових розладів, які, за даними досліджень (Шебанова, 2016; Branley, 2017; Marcus, 2016 та ін.), пов'язані 3 викривленим самосприйняттям (помилковою інтерпретацією власної тілесності). Серед психологічних особливостей осіб з розладами харчової поведінки відзначаються відчуття ізоляції і власної «ненормальності» 3 приводу надлишкової ваги (уявної чи реальної), суперечливість почуттів та розірваність Я-концепції, активність примітивних механізмів психологічного захисту, соматизація внутрішніх конфліктів, а також порушення соціальної адаптації (Шебанова, 2016).

Особи 3 харчовими розладами $\epsilon$ активними користувачами Інтернет-мережі, зокрема спеціалізованих сайтів, груп, що дозволяє їм обмінюватися інформацією та підтримкою і має значний вплив на їх свідомість і поведінку (Dickins, Thomas, King, Lewis \& Holland, 2011; Wooldridge, Mok \& Chiu, 2014; Branley \& Covey, 2017). Так, дослідження M. Dickins, S.L. Thomas, B. King, S. Lewis \& K. Holland (2011) показало, що інформація, розміщена на спеціалізованих блогах для осіб, які страждають на ожиріння і постійно стикаються зі стигматизацією, дозволяє їм перейти від реактивних стратегій 
у відповідь на стигму до ініціативних відповідей, що дозволяють протистояти стигмі. Вплив соціальних мереж на користувачів 3 проблемною харчовою поведінкою підтверджується D.B. Branley \& J. Covey (2017), які наголошують, що розробникам інформаційних та лікувальних заходів необхідно враховувати цей вплив i його можливі негативні наслідки, і відповідно, зосередитися на завданнях позитивної онлайн-підтримки.

Тож в умовах поширення Інтернет-комунікації актуальним $\epsilon$ вивчення специфіки онлайн-комунікації осіб 3 розладами харчової поведінки, що дозволить уточнити їх особливості, комунікативні стратегії та врахувати ці дані при розробці змісту і засобів психологічної допомоги. Особливого значення при цьому набуває психолінгвістичне дослідження особливостей мовної самопрезентації цих осіб в процесі онлайн-комунікації.

Мета статті - на основі психолінгвістичного аналізу нікнеймів ${ }^{*}$ визначити особливості мовної самопрезентації осіб 3 порушеннями харчової поведінки в процесі онлайн-комунікації.

Завдання дослідження: 1) дослідити особливості мовної самопрезентації в умовах Інтернет-комунікації осіб з порушеннями харчової поведінки, виокремивши основні іiі категорії; 2) виявити відмінності мовної самопрезентації осіб 3 анорексією та осіб із надмірною вагою в процесі онлайн-комунікації.

\section{Методи і методики дослідження}

Методологічною основою нашого дослідження стали підходи:

- психолінгвістичний, в межах якого текст розглядається як опредмечена форма акту комунікації; як продукт, створений мовною особистістю й адресований мовній особистості, як продукт діяльності людини, у якому втілюється й об'єднується його психологічний зміст, умови спілкування й особистість мовця (Овсієнко, 2013). Оскільки мовленнєва діяльність пронизує усі сфери особистісного буття, психолінгвістичні дослідження мають спрямовуватися на вивчення особистості та різних проявів іiї буття через грунтовне вивчення мовленнєвої діяльності і мови як основної складової свідомості людини (Засєкіна, 2008);

* Нікнейм (нік; англ. Nickname): ім'я в інтернет-мережі - псевдонім, який використовується користувачем під час спілкування (у блогах, форумах, чатах). 
- проективний, що базується на розумінні особистості як відносно стійкої системи взаємозалежних динамічних процесів, організованих на основі потреб, емоцій та індивідуального досвіду, які активно діють впродовж життя індивіда, формуючи, спрямовуючи, заломлюючи кожну ситуацію у внутрішньому світі індивіда. Відповідно до цього кожна дія, кожний емоційний прояв індивіда, його сприймання, почуття, висловлення, рухові акти несуть на собі відбиток особистості (Бурлачук, 2008).

Отже, нікнейм може розглядатися як джерело символічної інформації про його автора, як проекція особою власного способу бачення життя, думок i почуттів, внутрішнього світу, суб’єктивних переживань.

Методичний інструментарій дослідження передбачав аналіз та узагальнення праць, присвячених вивченню віртуального дискурсу; контент-аналіз символічної/знакової інформації (нікнеймів) у контексті виявлення особливостей мовної самопрезентації осіб 3 харчовими розладами у співвіднесенні з текстовими повідомленнями та самозвітами учасників спілкування, що дозволило отримати інформацію щодо актуальних питань, психоемоційних станів користувачів, особливостей їх харчової поведінки, самосприйняття. Емпіричне дослідження передбачало аналіз нікнеймів 237 осіб жіночої статі 3 харчовими розладами (126 відвідувачів сайту, присвяченого анорексії, 111 користувачів сайту корекції ваги, пацієнток клініки оздоровчого схуднення), які були користувачами спеціалізованих сайтів:

- портал anorex.ru (присвячений анорексії, булімії, ожирінню та способам боротьби з ними). Сайт позиціонується не просто як джерело інформації, а як місце для спілкування людей 3 подібними проблемами.

- caйm корекціï ваги (ves24.ru), що декларує місію об’єднання людей, які хочуть скорегувати свою вагу. Користувачам пропонуються онлайн-калькулятор калорій, блог-щоденник для планування та опису процесу схуднення, можливість коментарів адміністратора та інших учасників.

Задля визначення статистичної значущості відмінностей використовувався статистичний $\varphi^{*}$-критерій кутового перетворення Фішера. 


\section{Результати та дискусії}

У психологічних дослідженнях термін самопрезентаиія найчастіше використовується у зв'язку 3 самоусвідомленням особистості та соціальною взаємодією. Самопрезентація, що $\epsilon$ складовою процесу сприйняття людини людиною, розглядається як засіб відображення та формування образу Я й підтримки самооцінки, як демонстрація різних соціальних ролей та можливість представити себе найбільш привабливим чином (Бурнаева \& Затулий, 2012), як засіб організації своєї поведінки (Goffman, 1986).

В умовах Інтернет-спілкування самопрезентація комунікантів має певну специфіку (Войскунский, 2001; Бочелюк \& Панов, 2018; Шевченко, 2003 та ін.); вона представлена переважно у текстах користувачів, тобто у мовленнєвій формі, яка відображає рівень організації змісту досвіду особистості (Орап, 2014). Досліджуючи варіативність самопрезентації особистості в інтернет-спілкуванні, I. Шевченко відзначає два іiї аспекти: саморозкриття як повідомлення Іншим (партнерам) особистої інформації про себе; самопрезентація (намагання керувати враженнями Інших) як різні стратегії і тактики, які використовує людина з метою формування певного враження на партнера (партнерів) в Інтернет-спільноті (Шевченко, 2003).

Як зазначають дослідники, в Інтернет-комунікації особистість представлена не в усій своїй суб'єктності, а редуковано, як набір текстів, продукованих нею самою або іншими людьми про неї: самопрезентацій, реплік в чатах, на форумах тощо. Оскільки людина виявляється редукованою до набору вербальних повідомлень різного ступеню істинності й детальності, то саме на ці відомості спираються співрозмовники для орієнтування в партнері в процесі онлайн-комунікації (Войскунский, 2001; Бочелюк \& Панов, 2018). Тож в Інтернет-комунікації відбувається процес формування віртуальної особистості, яка шукає форми і способи вираження; при цьому технології цієї комунікації дають змогу залишатися неідентифікованою, що відкриває їй нові можливості для реалізації своїх інтенцій (Воробей, 2015).

Н. Акімова наголошує на таких ознаках Інтернет-комунікації, як анонімність і відвертість, що мають істотне значення для самопрезентації особистості в мережі. На іï думку, створений в Інтернеті образ - це переважно вигаданий або покращений образ 
власного Я. Анонімним він є тому, що комуніканти знають про суб'єкта лише те, що він хоче повідомити; цей образ легко видалити i репрезентувати зовсім інший. Така легкість створення особистості у мережі створює відчуття безпосередності спілкування й водночас безвідповідальності. 3 іншого боку, онлайн-комунікація передбачає відвертість, адже на сайті особиста інформація користувача стає відкритою для всіх або принаймні зареєстрованих користувачів певного ресурсу. Отже, співрозмовники ще до початку спілкування досить багато знають один про одного (Акімова, 2016), хоча ця інформація може бути й недостовірною.

Достовірність наданої у процесі самопрезентації інформації пов'язана 3 психологічним самопочуттям особи. Почуття внутрішнього благополуччя сприяє тому, що людина вважає можливим повідомити про себе інформацію, яка відповідає дійсності, і не має потреби у принциповій зміні власного образу. Загальне почуття внутрішнього неблагополуччя є вагомою причиною, яка зумовлює викривлення Я-образу в процесі самопрезентації, тож людина, пригнічена цим почуттям, часто користується можливістю зміни власного образу для спілкування в Інтернет-мережі (Шевченко, 2003).

Спілкування в Інтернет-мережі зазвичай відбувається не під власним ім'ям, а під псевдонімом - нікнеймом. Отже, останній, $\epsilon$ своєрідною «візитною карткою», яка презентується віртуальній спільноті для ідентифікації себе як віртуальної особистості, тому вибір псевдоніма $\epsilon$ важливим для особи, яка проводить багато часу в Інтернеті. В сучасних дослідженнях (Алексенко, 2000; Бурнаева \& Затулий, 2012; Шевченко, 2003; Lyons, Mehl \& Pennebaker, 2006 та ін.) «нікнейм» розглядається як втілення певної ментальної моделі особистості, і відповідно, може аналізуватися як 3 позицій різних психологічних напрямів, так і $з$ позиції психолінгвістики як комунікативне повідомлення.

Вважаємо, що «нік», як віртуальний образ себе, впливає не лише на інших, але й на саму людину, оскільки вона налаштовується на обрану роль та намагається відповідати ій. Подібну позицію знаходимо в інших дослідженнях (Алексенко, 2000; Воробей, 2015; Щербакова, 2009). Так, на думку Н. Щербакової, вдалий вибір «ніку» забезпечує особі успіх, зацікавленість інших - інформативну, особистісну, комунікативну (Щербакова, 2009). Ховаючись за 
вигаданим нікнеймом та чужою фотографією на аватарці, людина може проявляти себе у різних аспектах, хоча найчастіше робить це для того, щоб уникнути негативних моментів у спілкуванні (образ, залякування, деструктивної критики) або ж навпаки - проявити свою приховану (творчу) іпостась, популяризувати іiі (Воробей, 2015). Таким чином, нікнейм - це роль, образ, взятий напрокат. Обрана роль має певну специфіку мовної репрезентації, оскільки залежить від рівня освіченості людини, іiі культури, особистісного сприйняття образу і мети, з якою людина «входить» в Інтернет-спільноту.

Контент-аналіз нікнеймів користувачів форуму осіб 3 анорексією дозволив виокремити певні категорії, представлені у табл. 1.

Таблиця 1. Категорії нікнеймів користувачів форуму осіб з анорексією $(\mathrm{N}=126)$

\begin{tabular}{|c|c|c|}
\hline $\begin{array}{l}\text { Характер нікнейму } \\
\text { (категорія) }\end{array}$ & Приклади & $\begin{array}{c}\text { Розповсюдженість } \\
\text { типу, \% }\end{array}$ \\
\hline $\begin{array}{l}\text { Екзотично- } \\
\text { декоративне жіноче } \\
\text { ім'я }\end{array}$ & $\begin{array}{l}\text { Velena, Liona, Tata, Antonio, Iren, Angelika, } \\
\text { ophelia215, Aleksa@, Eglantine, Michelle, } \\
\text { Kate_Le, Nasty, erilin1991 }\end{array}$ & 19,0 \\
\hline \multirow[t]{2}{*}{$\begin{array}{l}\text { Метафоричні, } \\
\text { декоративно-загадкові } \\
\text { прізвиська }\end{array}$} & $\begin{array}{l}\text { Afterglow, Asya-White, Blümchen ( з нім. } \\
\text { квіточка), Pantera, coconut_girl, Liberty, } \\
\text { freshhh, Yes Please, minimekea, Lexx, }\end{array}$ & 12,0 \\
\hline & & $\Sigma=31$ \\
\hline $\begin{array}{l}\text { Деструктивний, } \\
\text { проблемний характер } \\
\text { «ніку» }\end{array}$ & $\begin{array}{l}\text { Lonely broken angel, , INNaya, Anirun, } \\
\text { WENDETTA1987, Utrata, Locust, RED } \\
\text { MORTIS, effi-drama, la_fripouille }\end{array}$ & 14,3 \\
\hline \multirow[t]{2}{*}{$\begin{array}{l}\text { Аноректичні / } \\
\text { тілесні ознаки, } \\
\text { які відображають } \\
\text { тілесний статус }\end{array}$} & $\begin{array}{l}\text { Anarex, invisible (невидимка), refined, } \\
\text { matreshka girl, Jambo, Praksia, Oks_AnaG, } \\
\text { invisible, realno tolstaya }\end{array}$ & 6,3 \\
\hline & & $\sum \approx 21$ \\
\hline $\begin{array}{l}\text { Міфічні та } \\
\text { фантазійні персонажі }\end{array}$ & $\begin{array}{l}\text { Shinji, jiketsu, Melamorie, Ephemera, } \\
\text { Shakty, Akemi, ariseorise }\end{array}$ & 5,6 \\
\hline $\begin{array}{l}\text { Індивідуальні, } \\
\text { характерні } \\
\text { особливості «ніку» }\end{array}$ & $\begin{array}{l}\text { VALERAYNKA, Fiorik, lublu-zubi, groove_ } \\
\text { me2nite, Moloday mama, acitamard, Foma, } \\
\text { Grelka, August2012, Doctor Dasha }\end{array}$ & 10,3 \\
\hline $\begin{array}{l}\text { Модифіковане власне } \\
\text { ім'я }\end{array}$ & $\begin{array}{l}\text { kirakira, VikToRia21, nasta-a-a, Renn, } \\
\text { Ekaterinanaaa, MARINNA, natali777, Irkin, } \\
\text { VEERAA, V.O.V.A. }\end{array}$ & 8,0 \\
\hline $\begin{array}{l}\text { Зменшено-пестливе } \\
\text { ім’я }\end{array}$ & $\begin{array}{l}\text { Irinushka, Arinka2013, Lyubasha, alenka } \\
\text { kisa 4, Ksun1993, Madinka, Kitsuna, } \\
\text { Nikochka, Natashenka }\end{array}$ & 8,0 \\
\hline
\end{tabular}


Nickname as a Means of Linguistic Self-Presentation in the Internet...

Реальні повсякденні імена
Екатерина, Светлана, Anna1983, nika77784, Кристина, Natasha, Kseniya, Мила, Nina
6,3

$$
\sum=14,3
$$

Емоційно-позитивний

Phany Unreal, WOW, mashaenjoy, Myau,

Polza, 2bethebest, Boogiegirl

wer6131, Ixxer, дд, olijh, koteg, JSm

5,6

4,8

Аналіз нікнеймів як засобу самопрезентації дозволяє стверджувати, що їх найпоширеніша категорія (19,0\% вибірки) представлена серед користувачів форуму осіб 3 анорексією екзотично-декоративними іменами, які мають помпезний, парадний характер. При цьому більшість подібних «ніків» супроводжуються відповідними екстравагантними аватарами, що підкреслюють ексцентричність авторів. На нашу думку, за вибором таких засобів самопрезентації приховується бажання підкреслити свою винятковість та привернути до себе увагу.

Інша частина користувачів згаданого форуму (12,0\%) також презентує себе за допомогою загадкових, привабливих mа декоративних нікнеймів, але вони мають метафоричний характер: Afterglow - вечірня зоря, післясяйво, Pantera, Ms. Princess, Vanilla_Sky тощо. Вважаємо, що автори цих нікнеймів також бажають привернути до себе увагу, підкреслюючи власну таємничість, загадковість і відсутність статі в самопрезентації. Загалом частка екзотичних та декоративно-загадкових нікнеймів у вибірці складає 31,0\%.

Серед осіб 3 анорексією достатньо чисельною $\epsilon$ категорія нікнеймів, які прямо транслюють особистісну драму, агресивний або депресивний стан (14,3\%), зокрема: Utrata, effi-drama, Lonely broken angel (одинокий зламаний ангел), End_Transmission (кінець передачі), Linda Weirdoman (від англ. сленгового weirdo - збоченець), la_fripouille (фр. - мерзотник, сволота), disorder. У певному сенсі різновидом цієї категорії $\epsilon$ імена, які мають майже прямі вказівки на проблему анорексії та підкреслюють викривлений образ власного тіла автора, наприклад: Anarex, invisible (невидимка), refined (витончена), matreshka girl, Jambo (ім'я слоненяти - персонажу дитячої казки) та інші. Частка подібних нікнеймів складає 6,3\%, а отже, сумарний відсоток за обома категоріями, які підкреслюють 
проблемну харчову поведінку, складає майже 21,0\%. На нашу думку, особи, які обирають подібні «ніки», прагнуть не тільки підкреслити свою незвичайність і унікальність, але й оголюють душу, акцентуючи іiі чуттєвість; демонстрація ними проблем може свідчити про непрямий запит на допомогу.

Окрему категорію загадкових нікнеймів склали міфічні ma фентезі-псевдоніми (5,5\% вибірки). «Ніки» цієї категорії не зрозумілі людям, які не знайомі з певною субкультурою (зокрема, персонажами аніме ${ }^{* *}$ ). Плеяда науковців (Алексенко, 2000; Шабшин, 2005; Щербакова, 2009 та ін.) відзначають, що багато людей 3 тими чи іншими обмеженнями компенсують власну недосконалість саме через намагання відтворювати характерологічні особливості поведінки свого кумира/іншої людини та намагаючись бути «гідними» обраного фан-імені (зовнішньо та внутрішньо). Водночас деколи «легендарне» ім'я обирається випадково, за словником, без усвідомлення змісту 3 орієнтацією лише на фонетичну привабливість слова.

Ще одна категорія нікнеймів користувачів цього форуму $(8,0 \%)$ представлена певними модифікаціями власного імені (подвоєння імені, подовження окремих його частин та інші втручання), наприклад: kirakira, VikToRia21, nasta-a-a, Renn, Ekaterinanaaa, MARINNA,VEERAA. Імовірно, така категорія ніків відображає схильність їх авторів до певних варіацій не тільки 3 власним іменем, але й до маніпуляцій з власним тілом.

У 8,0\% випадків нікнейм є модифікацію власного імені або псевдоніму шляхом додавання зменшувального суфіксу. На нашу думку, зменшено-пестливий псевдонім може вказувати на певну інфантилізацію особи та тенденцію «до зменшення»- свого віку, тіла та навіть значущості проблемної харчової ситуації (наприклад, у коментарях представники цієї групи часто пишуть: «не розумію, чого вони до мене чіпляються...я просто не хочу їсти»; «ну $i$ щзо $з$ того, щзо я періодично блюю...кожна людина по-своєму знімає стрес...зокрема, я саме через блювоту»). Аналіз наявного в Інтернет-чатах текстового масиву виявляє, що користувачі цієї категорії є емоційними особами - вразливими та сентиментальними,

** Особливий вид мистецтва - мальовані фільми виробництва Японії з характерним виглядом персонажів, які орієнтовані на підліткову та дорослу аудиторію, відрізняється характерною манерою відтворення персонажів і фонів. 
вони охоче діляться своїми страхами та різноманітними проблемами. Мета їхнього спілкування у мережі - зрозуміти: «що зі мною не так?». Серед найактуальніших питань, які вони обговорюють в чатах, окрім дієт, особливостей поведінки i харчування, питання, пов'язані 3 труднощами спілкування та особистісного зростання (як подолати невпевненість у собі, позбутися відчуття самотності, різноманітних страхів, почуття провини, надмірної сором'язливості тощо).

Аналіз нікнеймів осіб із зайвою вагою дозволив визначити наступні особливості їхньої самопрезентації (табл. 2).

Таблиця 2. Категорії нікнеймів осіб із зайвою вагою $(\mathrm{N}=111)$

\begin{tabular}{|c|c|c|}
\hline $\begin{array}{l}\text { Характер нікнейму } \\
\text { (категорія) }\end{array}$ & Приклади & $\begin{array}{l}\text { Розповсюдженість } \\
\text { типу, \% }\end{array}$ \\
\hline $\begin{array}{l}\text { Екзотично- } \\
\text { декоративне жіноче } \\
\text { iм'я }\end{array}$ & $\begin{array}{l}\text { Ameli, Єва, Lanita, ZUZU, Yanina, Dajzy, } \\
\text { Хелена, Nagina, Katrinka, Шейла, Лола, } \\
\text { Одри }\end{array}$ & 10,81 \\
\hline $\begin{array}{l}\text { Модифіковане } \\
\text { власне ім'я }\end{array}$ & $\begin{array}{l}\text { Kosninka, Марга, Тинка, Зимка, TinaG, } \\
\text { Alenka@86, Tatka, xLenax, Ганка, Anka, } \\
\text { ДАНA, Kate, Svetka, Ирка-дырка, Натка }\end{array}$ & 15,32 \\
\hline $\begin{array}{l}\text { Пов’язані з вагою } \\
\text { або параметрами } \\
\text { тіла (відображають } \\
\text { тілесний статус) }\end{array}$ & $\begin{array}{l}\text { Светик -60! (60-запланована вага), алла68 } \\
\text { (68 вага зара3), Spirit lighte, smallfox, } \\
\text { Bambolina, tonkaya_zvonkaya, Стройняшка, } \\
\text { Весы, Худобина, }\end{array}$ & 8,11 \\
\hline $\begin{array}{l}\text { За мотивами } \\
\text { харчових продуктів }\end{array}$ & $\begin{array}{l}\text { Pirozhochek, Bulka, Bramble (ожина), } \\
\text { Копченая жирная Рыбка, sazan, Жареная } \\
\text { хрюшка }\end{array}$ & 5,41 \\
\hline $\begin{array}{l}\text { Метафоричні, } \\
\text { декоративно- } \\
\text { загадкові ніки }\end{array}$ & $\begin{array}{l}\text { Raindrop, Atlantida, Нефертити, galaktika, } \\
\text { Ариадна, Дуновенье, Bead (намистинка), }\end{array}$ & 6,31 \\
\hline $\begin{array}{l}\text { Емоційно- } \\
\text { позитивний характер } \\
\text { ніків }\end{array}$ & $\begin{array}{l}\text { Ol.Lya.Lya, Solnce RadyGa, Zabava, } \\
\text { VeryHappyTwice, Raduga }\end{array}$ & 5,41 \\
\hline $\begin{array}{l}\text { Реальні повсякденні } \\
\text { імена }\end{array}$ & $\begin{array}{l}\text { TINA, ОльгаGl, Леся, Tatiyna, Margarita, } \\
\text { Ольга Владимировна, Ксюша, Инесса, } \\
\text { Мария, Оксана, Leela, Riwskaya, Snezhana }\end{array}$ & 18,02 \\
\hline $\begin{array}{l}\text { Зменшено-пестливе } \\
\text { ім'я }\end{array}$ & $\begin{array}{l}\text { Natysia, Милочка, Женичка, Cvetik, Ирчик, } \\
\text { Аришка, Svetochek, anjuta, Богдаша, Ляля, } \\
\text { оленька78, Татьянка, Ксюня } 888 \text {, Ksanochka }\end{array}$ & 12,61 \\
\hline $\begin{array}{l}\text { Індивідуальні, } \\
\text { характерні }\end{array}$ & $\begin{array}{l}\text { Телец, Вега, hotin, lider, nezabudka, не- } \\
\text { ангел, mehack, RomaIIIka, texac, Заноза, } \\
\text { Umka, Загадка, kattis, LA-DUSHKA, Идеал }\end{array}$ & 13,51 \\
\hline
\end{tabular}


Нікнейм як засіб мовної самопрезентації в Інтернеті осіб..

\begin{tabular}{llc} 
Міфічні & Геракл, Дездемона & 1,8 \\
Чоловічі імена & Magnum_45, Danil, Grisha & 2,7 \\
\hline
\end{tabular}

Найпоширенішими у вибірці осіб із зайвою вагою є реальні імена, які свідчать про те, що їх володарки не намагаються створити віртуальний Я-образ і приховати власну сутність. $18,0 \%$ користувачів вказують власні імена, не намагаючись їх трансформувати або прикрасити. 12,6\% вибірки обирають реальні імена, які мають зменшено-пестливу форму (Natysia, Милочка, Svetochek, Татьянка та ін.). Це інфантилізований варіант власного «Я», володарки якого потребують турботи, допомоги та лагідного ставлення від оточення; подібні імена можуть також відображати бажання жінок виглядати тендітніше, на противагу реальній масі тіла.

Інший специфічний для цієї вибірки варіант - модифікація власного імені через скорочення імені або додавання суфіксу $(-\kappa)$ : Kosninka, Тинка, Натка, Tatka, Anka тощо. Означена тенденція, на нашу думку, істотно відрізняє цю вибірку від жінок з анорексією. Зокрема, якщо останні, презентуючи себе, намагаються різними способами додати своїм мовним самопрезентаціям витонченості, сексуальності та декоративності, то у жінок із зайвою вагою спостерігається протилежна тенденція - їхні імена мають спрощений, буденний, навіть грубий характер. Імовірно, це пов'язано з розчаруванням, неприйняттям себе, втратою віри у можливість бажаних змін власного тіла, себе, свого життя.

Водночас 10,81\% вибірки реєструються під «ніками», що означають екзотично-декоративні жіночі імена - Ameli, Lanita, ZUZU, Yanina, Dajzy, Хелена, Шейла, Лола, Одри, але, порівняно 3 вибіркою осіб 3 анорексією, частка таких нікнеймів є значущо нижчою $(\mathrm{p} \leq 0,05)$. В цій групі жінок виокремлюється категорія нікнеймів, що відображає їх зацикленість на тілесному образі, зокрема на вазі. У змісті нікнеймів цієї категорії $(8,11 \%)$ відмічено дві протилежні тенденції: частина жінок досить прямо вказує на огрядність власного тіла (зокрема, Bambolina та ін.), але більшість нікнеймів має спрямованість на образ стрункого тіла, хоча іноді має саркастичний характер (Стройняшка, tonkaya_zvonkaya,

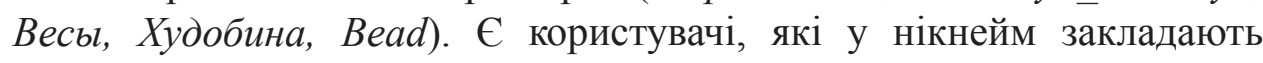


Nickname as a Means of Linguistic Self-Presentation in the Internet...

заплановану вагу - Светик-60!, або «стартову вагу» - алла68 (вага 68 кг на момент реєстрації на сайті). Більш завуальованою вказівкою на великі або малі розміри тіла є варіанти метафоричних імен (6,30\%), наприклад: Atlantida, galaktika, texac або Bead (намистинка), Дуновенье, Raindrop (дощова краплинка). У деяких випадках проекції є прямим та точним відображенням актуальних проблем людини.

Ще одну групу складає категорія нікнеймів за мотивами харчових продуктів (5,41\%) - Pirozhochek, Bulka, Bramble (ожина), Копченая жырная Рыбка, sazan, Жареная хрюшка, що може свідчити про фіксованість як на їжі, так і на вазі.

3 даних таблиць 1 та 2 можна скласти узагальнене уявлення про мовну самопрезентацію користувачів 3 різними типами порушень харчової поведінки. Щоб перевірити значущість відмінностей між групами, було використано $\varphi^{*}$-критерій кутового перетворення Фішера. Як видно 3 табл. 3, найбільші відмінності самопрезентацій жінок 3 різними типами харчових порушень стосуються деструктивних нікнеймів проблемного характеру $(\mathrm{p}=0,000)$ та «ніків» як реальних повсякденних імен $(\mathrm{p}=0,01)$.

Таблиця 3. Частотність прояву категорій нікнеймів користувачів специфічних форумів: осіб з анорексією та осіб із зайвою вагою (у\%)

\begin{tabular}{lccc}
\hline \multicolumn{1}{c}{ Категорія самопрезентації } & $\begin{array}{c}\text { Особи зі } \\
\text { знкеною } \\
\text { вагою }\end{array}$ & $\begin{array}{c}\text { Особи з } \\
\text { надмірною } \\
\text { вагою }\end{array}$ & $\begin{array}{c}\text { Статистична } \\
\text { значущість } \\
\text { відмінностей }\end{array}$ \\
\hline Екзотично-декоративне жіноче ім'я & 19,0 & 10,81 & 0,05 \\
Метафоричні, декоративно-загадкові & 12,0 & 6,31 & - \\
прізвиська & 5,6 & 1,8 & - \\
Міфічні та фантазійні персонажі & 14,3 & - & 0,000 \\
Деструктивний, проблемний образ & 6,3 & 8,11 & - \\
Імена, що відображають тілесний статус & - & 5,41 & 0,019 \\
За мотивами харчових продуктів & 5,6 & 5,41 & - \\
Емоційно-позитивний образ & 10,3 & 13,51 & - \\
Індивідуальні, характерні імена & 8,0 & 15,32 & 0,05 \\
Модифіковане власне ім'я & 8,0 & 12,61 & - \\
Зменшено-пестливе ім'я & 6,3 & 18,02 & 0,01 \\
\hline Реальні повсякденні імена & &
\end{tabular}


Нікнейм як засіб мовної самопрезентацї̈ в Інтернеті осіб...

Аналіз особливостей самопрезентації осіб 3 анорексією дозволяє визначити специфічні особливості їхніх нікнеймів: тяжіння до модифікації, декорування та невпізнанності реального імені; переважання екзотично-загадкового та сексуальнопривабливого характеру імен; значна частка імен $(14,4 \%)$ прямо вказують на деструктивно-депресивний стан особи. Отже, в осіб 3 анорексією фіксація на ідеалізованих пропорціях тіла зумовлює негативне ставлення до власного тіла, його викривлене сприйняття, аж до повного відторгнення, механізми втечі від реальності у фантастичний світ, інфантилізм.

Жінки, які реєструються на форумах осіб із зайвою вагою, значущо частіше $(\mathrm{p} \leq 0,01)$ презентують себе власними іменами. Значна частка модифікованих «ніків» $\epsilon$ похідними від власного імені (має або спрощену форму, або зменшено-пестливий характер). Специфічними для цієї групи користувачів $є$ нікнейми, що означають назви продуктів харчування та прямі або завуальовані натяки на великі параметри тіла. Отже, аналіз нікнеймів свідчить, що в осіб із зайвою вагою переважають такі механізми психологічного захисту, як дисоціація та заперечення, що допомагає їм дистанціюватися від проблеми переїдання; водночас в цій групі більш виражене усвідомлення проблеми.

Загальним для обох груп користувачів є вибір «ніків», які відображають їхні неповторні та унікальні особливості: риси характеру, соціальний статус, захоплення, дозволяють презентувати себе як носія позитивного емоційно-енергетичного заряду та певного тілесного статусу. При цьому якісні характеристики цих проекцій вказують на модальність ставлення до свого тіла та/або бажаність певних параметрів тіла.

Результати нашого дослідження мовної самопрезентації осіб 3 харчовими розладами в Інтернеті кореспондуються 3 даними інших досліджень у цій галузі. Так, вивчаючи самопрезентацію та ідентичність осіб з харчовими розладами, дослідники аналізують текстовий матеріал - комунікацію користувачів на форумах, в соціальних мережах, текстові повідомлення про тіло й тілесні переживання (Riley, Rodham \& Gavin, 2009, Bates, 2015, Gavin, Rodham \& Poyer, 2008; Lyons, Mehl \& Pennebaker, 2006; Teufel, Hofer, Junne et al., 2013). Зокрема, аналіз мовної репрезентації ідентичності користувачів сайтів «pro-anorexia» і «відновлення» 
(Riley, Rodham \& Gavin, 2009) виявив різні форми опису тіла, що втілюють ідеал, певні вимоги членства в цих групах, які для групи «рro-anorexia» повторно продукують ідентичності, пов'язані 3 харчовим розладом. В іншому дослідженні було використано дискурс-аналіз метафор, які використовують особи 3 анорексією для розповіді про себе в соціальній мережі, що дозволило виявити ключові метафоричні конструкції у їх самовизначеннях: «Я» як простір, «Я» як вага, вдосконалення себе і соціальне «Я», які являли собою стратегії дискурсу для створення як колективної, так і індивідуальної ідентичності (Bates, 2015).

Виявлені нами відмінності мовної самопрезентації у формі нікнеймів осіб з різними типами проблемної харчової поведінки, зокрема більш позитивна модальність самопрезентації осіб 3 надмірною вагою, підтверджуються даними інших досліджень. Порівняння таких Інтернет-спільнот виявило, що члени спільноти «fatosphere» (від «fat» - товстий, жирний) демонструють позитивність i самолюбство, використовуючи зображення, підписи та хеш-теги, які вказують на загальне відчуття щастя й позитивної енергії (Marcus, 2016). Члени спільноти «pro-anorexia» використовують зображення, пов'язані з важливістю втрати ваги, затінення, негативні хеш-теги, такі як \#depression, \#depressed i \#sad, що в цілому свідчить про негатив та незадоволення (Marcus, 2016). Також їм може бути властиве несвідоме відторгнення зрілої сексуальності, що приховується за створенням дитячого або лялькового образу (Бурнаева \& Затулий, 2012; Шабшин, 2005).

Порівняння результатів нашого дослідження 3 іншими підтверджує факт домінування жінок в Інтернет-спільнотах осіб 3 проблемами ваги. Це свідчить про більший соціальний тиск на жінок щодо стандартів зовнішнього вигляду, що зумовлює в них вищий рівень невдоволення своєю вагою і образом тіла, ніж в чоловіків, i змушує прагнути певних стандартів тіла (Marcus, 2016, Bates, 2015).

Як і інші дослідники в цій галузі (Branley \& Covey, 2017, Bates, 2015), ми вважаємо необхідним враховувати дані щодо специфіки мовної самопрезентації учасників Інтернет-спільнот 3 проблемами харчової поведінки, оскільки це може допомогти у розробці стратегій i засобів фахової допомоги. Доступність i анонімність Інтернету дає широкі можливості підтримки людей 3 харчовими розладами шляхом інтернет-консультування 
3 кваліфікованим психологом, який має здійснювати первинний контакт, надавати інформацію та спрямовувати їх до спеціалізованих клінік або терапевтів.

\section{Висновки}

Мовна самопрезентація у процесі Інтернет-комунікації дозволяє користувачу створювати власний віртуальний образ i керувати враженням партнерів по комунікації відповідно до цілей спілкування. Нікнем як атрибут мовної самопрезентації $\epsilon$ символічною проекцію реальної особистості 3 іiі досвідом, психологічними особливостями та проблемами. Зокрема, нікнейм як засіб мовної самопрезентації осіб з розладами харчової поведінки в Інтернеті часто відображає специфічну харчову проблему та самоставлення особи у зв'язку з нею.

В процесі аналізу на основі психолінгвістичного та проективного підходів виокремлено основні категорії нікнеймів осіб з анорексією та осіб із зайвою вагою: екзотично-декоративні імена; метафоричні, декоративно-загадкові прізвиська; міфічні та фантазійні персонажі; деструктивний, проблемний образ; імена, що відображають тілесний статус та ін. На основі контент-аналізу нікнеймів виявлено відмінності мовної самопрезентації цих груп користувачів, зокрема більш позитивну іiі модальність в осіб iз зайвою вагою, що пов'язане 3 різними механізмами копінгу. Нікнейми осіб з анорексією відображають фіксацію на ідеалізованих пропорціях тіла та негативне ставлення до власного тіла, його викривлене сприйняття аж до повного відторгнення, що виявляється у деструктивному, проблемному характері мовної самопрезентації; також поширені «ніки», що свідчать про психологічні механізми втечі від реальності у фантастичний світ, інфантилізм. Нікнейми осіб із зайвою вагою відзначаються реалізмом, мають спрощений або буденний характер, відображають фіксованість на проблемі їжі та ваги; їх позитивна модальність свідчить про переважання механізмів дисоціації та заперечення, що допомагає дистанціюватися від власної проблеми переїдання, водночас ці користувачі мають вищий рівень усвідомлення проблеми.

Аналіз нікнеймів як засобу самопрезентації $€$ корисним 3 метою як психодіагностики, так і професійної допомоги особам 
Nickname as a Means of Linguistic Self-Presentation in the Internet...

3 харчовими розладами. Здійснення такого аналізу $є$ доцільним під час встановлення контакту, первинної психодіагностики та психологічної допомоги таким особам.

\section{Література}

Акімова Н.В. Деякі фактори варіативності розуміння інтернет-комунікації. Науковий вісник Ізмаӥльського державного гуманітарного університету. 2016. Вип. 35. С. 123-128.

Алексенко Н.Н. Психоаналитические аспекты поведения человека в киберпространстве. Журнал практической психологии и психоанализа. 2000. № 3. С.91-107. [Электронный ресурс]. Режим доступа: http://psyjournal.ru/ articles/psihoanaliticheskie-aspekty-povedeniya-cheloveka-v-kiberprostranstve.

Бочелюк В., Панов М. Проблемне поле психолінгвістичних досліджень дискурсу соціальних онлайн-мереж. Psycholinguistics. Психолінгвістика. Психолингвистика. 2018. № 24(1). С. 79-96. https://doi.org/10.31470/23091797-2018-24-1-79-96

Бурлачук Л.Ф. Психодиагностика. 2-е изд., ред. и допол. Москва, Питер, 2008. $351 \mathrm{c.}$

Бурнаева Е.М., Затулий А.И. Гендерные идеалы: особенности самопрезентации пользователей интернета. Вестник ТОГУ. 2012. № 1(24). С. 297-304.

Войскунский А.Е. Развитие речевого общения как результат применения Интернета. Социальные и психологические последствия применения информационных технологий: материалы международной интернетконференции (20.03-14.05.2001) / под ред. А.В. Войскунского. Москва, 2001. C. 232-242.

Воробей Ю.В. Інтернет-комунікація та Інтернет-комунікант: взаємодія і взаємопородження. Science and Education a New Dimension. Philology. 2015. III(16). Issue 70. C. 43-46.

Горошко Е.И. Психолингвистика Интернет-коммуникаций. Bonpocbl психолингвистики. 2008. № 7. С. 5-12.

Жичкина А. Социально-психологические аспекты общения в Интернете. Москва: Дашков и Ко. 2004. 117 с.

Засєкіна Л.В. Психолінгвістика, мовленнєва діяльність, особистість: співвідношення понять у контексті мовленнєвої генези дитини. Гуманітарний вісник Переяслав-Хмельницького державного педагогічного університету імені Григорія Сковороди. Переяслав-Хмельницький, 2008. Вип. 15. С. 83-85.

Овсієнко Л. Текст як об'єкт вивчення психолінгвістики. Теоретична $і$ дидактична філологія. 2013. Вип. 15. С. 58-69.

Орап М.О. Психологія мовленнєвого досвіду особистості. Тернопіль: Підручники і посібники, 2014. 480 с.

Шабшин И.И. Психологические особенности и феномены коммуникации в Интернете. Московский психотерапевтический журнал. 2005. № 1. С. 158-182.

Шебанова В.І. Феноменологія харчової поведінки в континуумі «норма патологія». Херсон: Видавництво Вишемирського В.С., 2016. 612 с.

Шевченко И.С. Вариативность самопрезентации личности в Интернет-общении : дисс ... канд. психол. наук. Казань, 2003. 170 с. 
Щербакова Н.В. Псевдонім для віртуальної особистості. Psycholinguistics. Психолінгвістика. Психолингвистика. 2009. Вип. 3. С. 179-183.

Branley, D.B., \& Covey, J. (2017). Pro-ana versus Pro-recovery: A Content Analytic Comparison of Social Media Users' Communication about Eating Disorders on Twitter and Tumblr. Frontiers in psychology, 11(8), 13-56. https://doi. org/10.3389/fpsyg.2017.01356

Dickins, M., Thomas, S.L., King, B., Lewis, S., \& Holland, K. (2011). The role of the Fatosphere in fat adults' responses to obesity stigma: A model of empowerment without a focus on weight loss. Qualitative Health Research, 21(12), 1679-91. https://doi.org/10.1177/1049732311417728

Bates, F.C. (2015). «I am a waste of breath, of space, of time»: Metaphors of self in a pro-anorexia group. Qualitative Health Research, 25, 189-204. https://doi. org/10.1177/1049732314550004

Gavin, J., Rodham, K., \& Poyer, H. (2008). The presentation of «pro-anorexia» in online group interactions. Qualitative Health Research, 18, 325-333. https://doi. org/10.1177/1049732307311640

Goffman, E. (1986). Stigma: Notes on the Management of Spoiled Identity. Reissue edition. N.Y.: Prentice-Hall.

Lyons, E.J., Mehl, M.R., \& Pennebaker, J.W. (2006). Pro-anorexics and recovering anorexics differ in their linguistic Internet self-presentation. Journal of Psychosomatic Research, 60, 253-256. https://doi.org/10.1016/j. jpsychores.2005.07.017

Marcus, S.-R. (2016). Thinspiration vs. thicksperation: Comparing pro-anorexic and fat acceptance image posts on a photo-sharing site. Cyberpsychology: Journal of Psychosocial Research on Cyberspace, 10(2). https://doi.org/10.5817/CP2016-2-5

Riley, S., Rodham, K., \& Gavin, J. (2009). Doing weight: Pro-ana and recovery identities in cyberspace. Journal of Community \& Applied Social Psychology, 19, 348-359. https://doi.org/10.1002/casp.1022

Teufel, M., Hofer, E., Junne, F., Sauer, H., Zipfel, S., \& Giel, K.E. (2013). A comparative analysis of anorexia nervosa groups on Facebook. Eating and Weight Disorders-Studies on Anorexia, Bulimia and Obesity, 18(4), 413-20. https://doi.org/10.1007/s40519-013-0050-y

Wooldridge, T., Mok, C., \& Chiu, S. (2014). Content analysis of male participation in pro-eating disorder web sites. Eating Disorders, 22(2), 97-110. https://doi.org/10. $1080 / 10640266.2013 .864891$

\section{References}

Akimova, N.V. (2016). Deyaki faktory variativnosti rozuminnya Internet-komunikatsiyi [Some factors of the variability of understanding of Internet-communication]. Naukoviy visnyk Izmayilskogo derzhavnogo gumanitarnogo universitetu Scientific Bulletin of the Izmail State Humanitarian University, 35, 123-128 [in Ukrainian].

Alexenko, N.N. (2000). Psihoanaliticheskie aspekty povedeniya cheloveka v kiberprostranstve [Psychoanalytic aspects of human behavior in cyberspace]. Zhurnal prakticheskoy psihologii $i$ psihoanaliza - Journal of Practical Psychology and Psychoanalysis, 3, 91-107. Retrieved from http://psyjournal. 
ru/articles/psihoanaliticheskie-aspekty-povedeniya-cheloveka-v-kiberprostranstve [in Russian].

Bochelyuk, V., \& Panov, M. (2018). Problemne pole psiholIngvIstichnih doslidzhen diskursu sotsialnyh onlayn-merezh [The problem field of psycholinguistic studies of the discourse of social online networks]. Psiholingvistika - Psycholinguistics, 24(1), 79-96. https://doi.org/10.31470/2309-1797-2018-24-1-79-96 [in Ukrainian].

Burlachuk, L.F. (2008). Psihodiagnostika [Psychodiagnostics] (2nd ed., rev.). Moscow, Peter [in Russian].

Burnayeva, E.M., \& Zatulii, A.I. (2012). Gendernyie idealyi: osobennosti samoprezentatsii polzovateley interneta [Gender Ideals: Peculiarities of SelfRepresentation of Internet Users]. Vestnik TOGU - Almanac TOGU, 1(24), 297304 [in Russian].

Voiskunsky, A.E. (2001). Razvitie rechevogo obshhenija kak rezultat primenenija Interneta [Development of Speech Communication as a Result of Use of the Internet]. Proceedings from SPPPIT'01: Mezhdunarodnaja internet-konferencija na inf.-obrazovatelnom portale www.auditorium/ru «Socialnye $i$ psihologicheskie posledstvija primenenija informacionnyh tehnologij» - The International Online Conference on the Information and Educational Portal www.auditorium/ru "Social and Psychological Consequences of the Application of Information Technologies». (pp. 232-242). Moscow [in Russian].

Vorobey, Yu.V. (2015). Internet-komunikatsiya ta Internet-komunikant: vzaemodiya i vzaemoporodzhennya [Internet communication and Internet communicator: interaction and intercourse]. Science and Education a New Dimension. Philology, III(16), Issue 70, 43-46 [in Ukrainian].

Goroshko, E.I. (2008). Psiholingvistika Internet-kommunikacij [Psycholinguistics of Internet Communications]. Voprosy psiholingvistiki - Journal of Psycholinguistics, 7, 5-12 [in Russian].

Zhichkina, A. (2004). Sotsialno-psihologicheskie aspekty obscheniya v Internete [Sociopsychological aspects of communication on the Internet]. Moscow: Dashkov i Ko [in Russian].

Zasekina, L.V. (2008). Psiholingvistika, movlenneva diyalnist, osobistist: spivvidnoshennya ponyat $\mathrm{u}$ konteksti movlennevoyi genezy dytyny [Psycholinguistics, speech activity, personality: correlation of concepts in the context of the child's speech genesis]. Gumanitarniy visnik PereyaslavHmelnitskogo derzhavnogo pedagogichnogo universitetu imeni Grigoriya Skovorody - Humanitarian Almanac of the Pereyaslav-Khmelnytsky State Pedagogical University named Gregory Skovoroda, 15, 83-85 [in Ukrainian].

Ovsienko, L. (2013). Tekst yak ob'ekt vyvchennya psiholingvistiki [Text as an object of studying psycholinguistics]. Teoretichna $i$ didaktichna filologiya - Theoretical and didactic philology, 15, 58-69 [in Ukrainian].

Orap, M.O. (2014). Psihologiya movlennevogo dosvidu osobistosti [Psychology of the person's speech experience]. Ternopil: Textbooks and manuals [in Ukrainian].

Shabshin, I.I. (2005). Psihologicheskie osobennosti i fenomenyi kommunikatsii v Internete [Psychological features and phenomena of communication on the Internet]. Moskovskiy psihoterapevticheskiy jurnal - Moscow Psychotherapeutic Journal, 1, 158-182 [in Russian].

Shebanova, V.I. (2016). Fenomenologiya harchovoyi povedinki v kontinuumi «norma patologiya» [Phenomenology of food behavior in the continuum "norm pathology»]. Kherson: Publishing House of Vyshemirsky V.S. [in Ukrainian]. 
Shevchenko, I.S. (2003). Variativnost samoprezentatsii lichnosti v Internet-obschenii [Variability of self-presentation of the person in Internet communication]. Candidate's thesis. Kazan [in Russian].

Scherbakova, N.V. (2009). Psevdonim dlya virtualnoyi osobystosti [Nickname for virtual person]. Psiholingvistika - Psycholinguistics, 3, 179-183 [in Ukrainian].

Branley, D.B., \& Covey, J. (2017). Pro-ana versus Pro-recovery: A Content Analytic Comparison of Social Media Users' Communication about Eating Disorders on Twitter and Tumblr. Frontiers in psychology, 11(8), 13-56. https://doi. org/10.3389/fpsyg.2017.01356

Dickins, M., Thomas, S.L., King, B., Lewis, S., \& Holland, K. (2011). The role of the Fatosphere in fat adults' responses to obesity stigma: A model of empowerment without a focus on weight loss. Qualitative Health Research, 21(12), 1679-91. https://doi.org/10.1177/1049732311417728

Bates, F.C. (2015). «I am a waste of breath, of space, of time»: Metaphors of self in a pro-anorexia group. Qualitative Health Research, 25, 189-204. https://doi. org/10.1177/1049732314550004

Gavin, J., Rodham, K., \& Poyer, H. (2008). The presentation of «pro-anorexia» in online group interactions. Qualitative Health Research, 18, 325-333. https://doi. org/10.1177/1049732307311640

Goffman, E. (1986). Stigma: Notes on the Management of Spoiled Identity. Reissue edition. N.Y.: Prentice-Hall.

Lyons, E.J., Mehl, M.R., \& Pennebaker, J.W. (2006). Pro-anorexics and recovering anorexics differ in their linguistic Internet self-presentation. Journal of Psychosomatic Research, 60, 253-256. https://doi.org/10.1016/j. jpsychores.2005.07.017

Marcus, S.-R. (2016). Thinspiration vs. thicksperation: Comparing pro-anorexic and fat acceptance image posts on a photo-sharing site. Cyberpsychology: Journal of Psychosocial Research on Cyberspace, 10(2). https://doi.org/10.5817/CP2016-2-5

Riley, S., Rodham, K., \& Gavin, J. (2009). Doing weight: Pro-ana and recovery identities in cyberspace. Journal of Community \& Applied Social Psychology, 19, 348-359. https://doi.org/10.1002/casp.1022

Teufel, M., Hofer, E., Junne, F., Sauer, H., Zipfel, S., \& Giel, K.E. (2013). A comparative analysis of anorexia nervosa groups on Facebook. Eating and Weight Disorders-Studies on Anorexia, Bulimia and Obesity, 18(4), 413-20. https://doi.org/10.1007/s40519-013-0050-y

Wooldridge, T., Mok, C., \& Chiu, S. (2014). Content analysis of male participation in pro-eating disorder web sites. Eating Disorders, 22(2), 97-110. https://doi.org/10. $1080 / 10640266.2013 .864891$

\section{АНОТАЦІЯ}

у статті проаналізовано особливості мовної самопрезентачії користувачів Інтернет-мережі. Наведено результати дослідження нікнеймів як засобів мовної самопрезентації осіб з харчовими розладами на спеціалізованих інтернет-форумах.

Представлено психологічний аналіз нікнеймів користувачів сайтів осіб з анорексією та осіб із зайвою вагою, який дає можливість стверджувати, 
що нікнейми відображають специфічну харчову проблему та самоставлення людини у зв'язку з нею. Виявлено переважання жіночої аудиторії таких сайтів, а відтак і більшу актуальність проблеми стандартів тіла для жінок. В процесі аналізу на основі психолінгвістичного та проективного підходів виокремлено основні категорії нікнеймів: екзотично-декоративні імена; метафоричні, декоративно-загадкові прізвиська; мірічні та франтазійні персонажі; деструктивний, проблемний образ; імена, що відображають тілесний статус та ін.

Встановлено, що нікнейми як атрибути мовної самопрезентації користувачів спеціалізованих форумів, $\epsilon$ символічною проекцією дискурсу їх буття і виявляють особливості реальних або бажаних параметрів тіла; незадоволеність вагою, своїм тілом, собою і життям в цілому; фіксованість на проблемі харчування та зниження ваги; прагнення відгородитися від реальності. Виявлено відмінності мовної самопрезентації осіб з анорексією та осіб із зайвою вагою, зокрема більш позитивну модальність самопрезентації осіб із зайвою вагою; представленість різних категорій мовної самопрезентації у цих групах, що дозволяє стверджувати про відмінність механізмів психологічного захисту у цих групах користувачів. Аналіз особливостей нікнеймів як засобу мовної самопрезентації $\epsilon$ корисним як з метою психодіагностики осіб з харчовими розладами, так і в процесі розробки і надання їм психологічної допомоги.

Ключові слова: Інтернет-комунікація, мовна самопрезентація особистості, дискурс-аналіз, нікнейм, порушення харчової поведінки.

\section{Шебанова Виталия, Яблонская Татьяна. Никнейм как средство речевой самопрезентации в Интернете лиц с нарушениями пищевого поведения}

\section{АННОТАЦИЯ}

В статье проанализированы особенности речевой самопрезентации пользователей Интернет-сети. Приведены результаты исследования никнеймов как средств речевой самопрезентации лиц с пищевыми расстройствами на специализированных Интернет-форумах.

Представлен психологчческий анализ никнеймов пользователей сайтов лиц с анорексией и лиц с лишним весом, который дает возможность утверждать, что никнеймы отражают специфическую пищевую проблему и самоотношение человека в связи с ней. Выявлено преобладание женской аудитории таких сайтов, а соответственно, и большую актуальность проблемы стандартов тела для женщин. В процессе анализа на основе психолингвистического и проективного подходов выделены основные категории никнеймов: экзотично-декоративные имена; метафорические, декоративнозагадочные прозвища; мифические и фантазийные персонажи; деструктивный, проблемный образ; имена, отражающие телесный статус и др.

Установлено, что никнеймы как атрибуты речевой самопрезентации пользователей специализированных форумов являются символической 
проекцией дискурса их бытия и выявляют особенности реальных или желаемых параметров тела; неудовлетворенность весом, своим телом, собой и жизнью в целом; фиксированность на проблеме питания и снижения веса; желание отстраниться от реальности. Выявлены отличия речевой самопрезентации лиц с анорексией и лиц с лишним весом, в частности более позитивная модальность самопрезентация лиц с лишним весом; представленность разных категорий речевой самопрезентации в этих группах, что позволяет утверждать о различиях механизмов психологической защиты в этих группах пользователей. Анализ особенностей никнеймов как средства речевой самопрезентации является полезным как с целью психодиагностики лиц с пищевыми расстройствами, так и в процессе разработки и предоставления им психологической помощи.

Ключевые слова: Интернет-коммуникация, речевая самопрезентация личности, дискурс-анализ, никнейм, нарушения пищевого поведения. 